\title{
Peningkatan Motivasi Berprestasi Dan Hasil Belajar Matematika Pada Materi Transformasi Geometri Siswa Kelas Xi Tsm - 1 SMK Muhammadiyah 2 Jogoroto Melalui Pembelajaran Model Discovery Learning
}

\author{
Muhammad Agus fanani ${ }^{1}$, Suyoto ${ }^{2}$ \\ SMK Muhammadiyah 2 Jogoroto ${ }^{1}$ \\ Email: elfansay87@gmail.com \\ Program Studi PPG, Universitas Muhammadiyah Gresik ${ }^{2}$
}

\begin{abstract}
Abstrak
Penelitian ini bertujuan untuk mengetahui sejauhmana penerapan pembelajaran model Discovery Learning berbantuan media Power Point dan LKS meningkatkan motivasi berprestasi dan hasil belajar matematika siswa. Penelitian ini merupakan Penelitian Tindakan Kelas (PTK) yang dilaksanakan dalam 2 siklus, masing-masing siklus terdiri atas empat tahapan yaitu: perencanaan, tindakan, observasi, dan refleksi. Subjek dalam penelitian tindakan ini adalah siswa kelas XI TSM 1 Semester Gasal SMK Muhammadiyah 2 Jogoroto tahun pelajaran 2019/2020 dengan jumlah siswa sebanyak 22 orang. Teknik pengumpulan data menggunakan teknik observasi, angket, catatan lapangan, dan tes. Analisis data dilakukan dengan model analisis interaktif yang terdiri dari proses pengumpulan data, penyajian data, dan verifikasi data. Hasil dari penelitian ini menunjukkan bahwa motivasi berprestasi dan hasil belajar siswa pada aspek pengetahuan dan keterampilan meningkat. Hal ini ditunjukkan dengan meningkatnya skor rata-rata motivasi berprestasi siswa pada tahap Pra Siklus, Siklus I, II adalah 45; 75; dan 77. Pada aspek pengetahuan, nilai rata-rata kelas pada tahap Pra Siklus, Siklus I dan II adalah 45; 75; dan 77. Pada aspek keterampilan nilai rata-rata kelas pada tahap Pra Siklus, Siklus I dan II adalah 60; 80; dan 85. Berdasarkan hasil tindakan dan analisis, penelitian ini menyimpulkan bahwa penerapan pembelajaran model discovery learning berbantuan Power Point dan LKS dapat meningkatkan motivasi berprestasi dan hasil belajar pada mata pelajaran matematika siswa kelas XI TSM 1 SMK Muhammadiyah 2 Jogoroto tahun pelajaran 2019/2020.
\end{abstract}

Katakunci: Motivasi berprestasi, hasil belajar matematika, Discovery Learning

\section{Abstrack}

This study aims to determine the extent of the application of Discovery Learning models with the help of Power Point and LKS media to increase achievement motivation and student mathematics learning outcomes. This research is a Classroom Action Research (CAR) carried out in 2 cycles, each cycle consisting of four stages: planning, action, observation, and reflection. The subjects in this action research were students of class XI TSM 1 Odd Semester of SMK Muhammadiyah 2 Jogoroto in the academic year $2019 / 2020$ with a total of 22 students. Data collection techniques using observation techniques, questionnaires, field notes, and tests. Data analysis was performed with an interactive analysis model consisting of the process of collecting data, presenting data, and verifying data. The results of this study indicate that achievement motivation and student learning outcomes in aspects of knowledge and skills increase. This is indicated by the increase in the average score of students' achievement motivation in the Pre-Cycle stage, Cycle I, II is 45; 75; and 77. In the aspect of knowledge, the average grade in the Pre-Cycle, Cycle I and II stages is $45 ; 75$; and 77. In the aspect of skills the average grade in the Pre-Cycle, Cycle I and II stages is 60; 80; and 85. Based on the results of actions and analysis, this study concluded that the application of discovery learning 
models assisted by Power Point and worksheets can increase achievement motivation and learning outcomes in mathematics subjects in class XI TSM 1 SMK Muhammadiyah 2 Jogoroto in the 2019/2020 academic year.

Keywords: Achievement Motivation, Mathematics Learning Outcomes, Discovery Learning

\section{PENDAHULUAN}

Salah satu upaya pemerintah meningkatkan kualitas pendidikan adalah melakukan perubahan terhadap Kurikulum 2006 menjadi Kurikulum 2013. Kurikulum 2013 menurut Permendikbud nomor 81A tahun 2013 tentang implementasi kurikulum, menganut pandangan dasar bahwa pengetahuan tidak dapat dipindahkan begitu saja dari guru ke siswa. Siswa adalah subjek yang memiliki kemampuan untuk secara aktif mencari, mengolah, mengkonstruksi, dan menggunakan pengetahuan.

Dari hasil pengamatan dan wawancara dengan teman-teman guru yang mengajar matematika di SMK Muhammadiyah 2 Jogoroto, terdapat gambaran bahwa masih banyak siswa yang mengeluh tentang sulitnya belajar matematika. Siswa sering menunjukkan rasa kurang tertarik/ kesulitan dan merasa bosan ketika belajar matematika. Hal itu ditunjukkan dengan nilai rata-rata ulangan harian kelas XI TSM 1 belum mencapai ketuntasan belajar. Berdasarkan observasi yang dilakukan di kelas, diperoleh beberapa kondisi yang menunjukkan bahwa: (1) hampir $60 \%$ siswa belum menguasai konsep matematika, sehingga siswa merasa kesulitan dalam mengerjakan soal-soal; (2) siswa belum terbiasa untuk berdiskusi secara berkelompok; (3) siswa sering mengalami kesulitan dalam menyelesaikan permasalahan pada buku siswa apabila soal yang diberikan sedikit berbeda dengan permasalahan sebelumnya; aktivitas belajar siswa yang belum maksimal dapat diamati dengan hanya $10 \%$ siswa yang bertanya selama proses pembelajaran berlangsung, dan siswa belum berani mengemukakan pendapatnya saat berdiskusi. Di antara berbagai faktor yang memicu hal tersebut di atas adalah proses pembelajaran yang kurang asyik dan menarik. Model pembelajaran yang sering ditemui pada pembelajaran matematika adalah "teacher centered", yaitu pembelajaran yang berpusat pada guru. Siswa cenderung pasif dan tidak berperan selama proses pembelajaran, sehingga proses yang muncul adalah "take and give". Dalam merangkai 
pembelajaran, guru pada umumnya terbiasa dengan model standar, yakni pembelajaran yang bermula dari rumus, menghapalnya, kemudian diterapkan dalam contoh soal. Selain itu guru juga belum memanfaatkan media pembelajaran yang tepat dalam proses pembelajaran. Model pembelajaran yang demikian tidak memberi ruang bagi siswa untuk melakukan observasi (mengamati), eksplorasi (menggali), inkuiri (menyelidiki), dan aktivitas-aktivitas lain yang memungkinkan mereka terlibat dan memahami permasalahan yang sesungguhnya. Model seperti ini yang mengakibatkan matematika hanya kumpulan rumus yang menyeramkan, sulit dipelajari, dan nampak abstrak.

Faktor lain yang mempengaruhi keberhasilan suatu proses pembelajaran adalah siswa itu sendiri. Pembelajaran harus menjadi sebuah aktivitas yang berfokus pada siswa (learned centered). Sistem pembelajaran yang efektif dan efisien mempertimbangkan komponen karakteristik siswa (Benny A. Pribadi., 2011:31). Beberapa karakteristik umum siswa antara lain: kondisi sosial ekonomi, kecerdasan, motivasi belajar, gaya belajar, dan lain-lain. Hampir semua siswa beranggapan bahwa matematika merupakan pelajaran yang sulit untuk dipahami. Hal ini tidak mengherankan karena matematika yang konsepnya tersusun secara hierarkhis dari yang mudah atau sederhana meningkat ke yang sulit atau rumit. Dengan demikian jika siswa belum dapat menguasai konsep yang mendasar maka siswa akan mengalami kesulitan menguasai konsep yang lebih lanjut. Umumnya, dalam mempelajari pelajaran yang dianggap sulit, siswa cenderung menunjukkan minat belajar dan motivasi yang rendah untuk berprestasi. Hal ini didukung oleh pendapat Dienes dalam Herman Hudoyo (1979:108) bahwa belajar matematika melibatkan suatu struktur hirarki dari konsep-konsep tingkat lebih tinggi yang dibentuk atas dasar apa yang telah terbentuk sebelumnya. Jadi, asumsi ini berarti bahwa belajar konsep-konsep matematika tingkat lebih tinggi tidak mungkin dapat berhasil baik bila prasyarat yang mendahului konsep-konsep itu belum dipelajari. Padahal dengan karakteristiknya yang khas, matematika seharusnya menjadi pelajaran yang menantang sehingga menarik minat belajar dan rasa ingin tahu yang besar. Sedangkan motivasi yang kuat untuk berprestasi menyebabkan siswa tidak cepat marasa puas dengan apa yang telah diraihnya. 
Sehubungan dengan itu muncul masalah, kenyataan menunjukkan ternyata siswa SMK Muhammadiyah 2 Jogoroto mempunyai motivasi berprestasi yang rendah untuk belajar matematika. Hal ini tampak pada saat kegiatan belajar mengajar berlangsung, banyak siswa yang sebenarnya kurang jelas tetapi tidak berani bertanya kepada guru, sehingga pada saat dilakukan ujian/tes, hasilnya tidak sesuai dengan harapan. Bahkan banyak siswa juga bersikap apatis dan masa bodoh dengan pelajaran matematika karena mereka menganggap hasilnya tidak akan jauh berbeda, karena sudah tidak faham dan merasa sulit dari awal, sudah demikian mengakar dalam benak mereka, sehingga untuk mengubah pemahaman keliru tersebut dibutuhkan waktu yang amat lama dan secara terus-menerus dilakukan. Rendahnya motivasi berprestasi belajar matematika juga dapat dilihat dari banyaknya siswa yang tidak mengerjakan tugas, yang apabila hal itu ditanyakan oleh guru, maka alasan yang dipakai siswa adalah karena mereka kurang jelas dengan apa yang sudah diberikan oleh guru.

Bagaimana meningkatkan motivasi berprestasi dan hasil belajar siswa dalam mata pelajaran matematika merupakan tanggung jawab guru matematika pada khususnya dan seluruh stake holder sekolah pada umumnya. Bagaimana guru dalam pembelajaran mampu menciptakan suasana belajar yang menyenangkan, menarik, menantang, kreatif, inovatif sehingga dapat meningkatkan kemampuan, pemahaman dan minat siswa terhadap pelajaran matematika merupakan hal penting yang tidak bisa diabaikan begitu saja.

Salah satu alternatif untuk meningkatkan motivasi berprestasi dan hasil belajar matematika siswa adalah melalui penerapan pembelajaran menggunakan Model Discovery Learning. Adapun dalam pelaksanaan menggunkaan stimulation (pemberian rangsangan), Problem statement (pernyataan/identifikasi masalah), Data collection (Pengumpulan Data), Data Processing (Pengolahan Data), Verification (Pembuktian), Generalization (menarik kesimpulan). Model pembelajaran ini diyakini dapat meningkatkan motivasi berprestasi siswa dalam belajar matematika, karena dalam model pembelajaran ini siswa diberi kesempatan untuk mengeksploitasi kemampuan masingmasing individu, tanpa harus merendahkan kemampuan teman yang lain. 


\section{METODE}

Penelitian ini bertujuan untuk meningkatkan motivasi berprestasi dan hasil belajar matematika siswa melalui pembelajaran model Discovery Learning berbantuan media Power Point dan LKS di kelas XI TSM-1 SMK Muhammadiyah 2 Jogoroto, maka penelitian yang dilakukan adalah penelitian tindakan kelas. Penelitian ini menggunakan pendekatan kuantitatif dan kualitatif.

Penelitian ini dibagi dalam beberapa tahap. Tahap-tahap dalam pelaksanaan penelitian adalah:

Tahap perencanaan meliputi penyusunan proposal, penyusunan rancangan penelitian, dan penyusunan instrumen penelitian. (2) Tahap Pelaksanaan. Tindakan dilakukan dalam beberapa siklus pembelajaran dan pada setiap akhir siklus diadakan tes prestasi belajar matematika. (3) Tahap Penyelesaian. Pada tahap ini dilakukan analisis data dan penyusunan laporan penelitian.

Penelitian ini merupakan Penelitian Tindakan Kelas (PTK). Rancangan utama dalam penelitian tindakan kelas ini memiliki empat tahapan, yaitu perencanaan (planning), pelaksanaan tindakan (acting), pengamatan (observating), dan refleksi (reflecting). Keempat langkah tersebut membentuk siklus yang dilakukan beberapa kali dengan tingkat keberhasilan penanganan masalah yang telah dipilih untuk diatasi. Adapun alur Penelitian Tindakan Kelas adalah sebagai berikut:

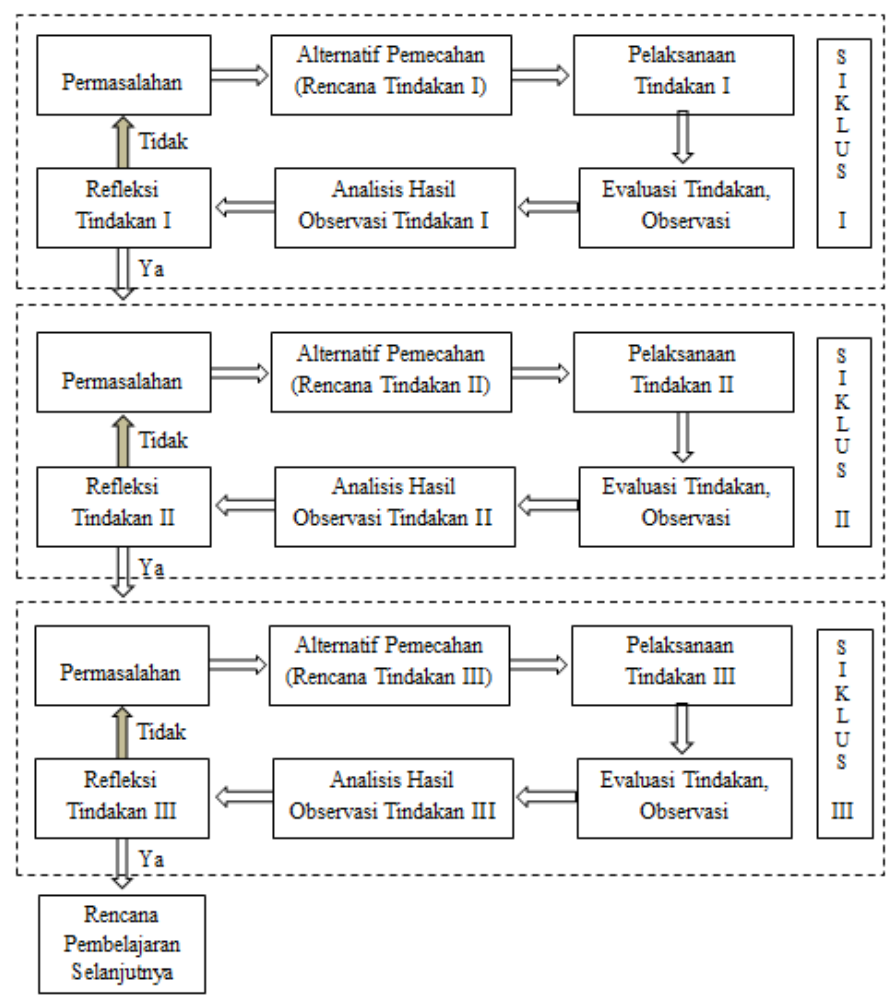

\section{Gambar III-1. Alur Penelitian Tindakan Kelas}

(Adopsi dari Heris Hendriana, 2014: 123)

Teknik pengumpulan data berupa teknik tes dan non tes. Teknik tes digunakan untuk mendapatkan skor hasil belajar. Teknik non tes dengan menggunakan: (1) Angket. Instrumen yang digunakan adalah angket motivasi berprestasi. (2) Catatan lapangan, berfungsi untuk mencatat kejadiankejadian di lapangan yang akan mendukung pengamatan. wawancara, digunakan untuk 
mendapatkan data pendukung yang ditujukan kepada guru yang melaksanakan pembelajaran juga beberapa siswa yang menonjol pada saat pembelajaran. (4) Observasi dan dokumentasi, Teknik observasi dan dokumentasi digunakan untuk mengumpulkan data kegiatan siswa dan guru selama proses pembelajaran.

Analisis data dalam penelitian ini dilakukan secara deskriptif kuantitatif dan kualitatif. Penyajian data dilakukan dalam bentuk uraian singkat, bagan, grafik dan bagan hubungan antar kategori atau dengan teks yang berbentuk naratif pada masing-masing siklus. Kesimpulan dalam penelitian merupakan temuan-temuan baru yang terjadi selama proses penelitian. Verifikasi dilakukan dengan bukti dari data-data yang diperoleh di lapangan selama penelitian untuk mendukung kesimpulan. Data penelitian yang terkumpul, setelah ditabulasi kemudian dianalisis untuk mencapai tujuan-tujuan penelitian. Analisis yang digunakan adalah teknik deskriptif analitik

\section{HASIL DAN PEMBAHASAN}

Hasil Penelitian Tindakan Kelas yang dilangsungkan dalam dua siklus, dapat diringkas dalam beberapa tabel di bawah ini.

\section{Motivasi berprestasi}

Peningkatan skor rata-rata motivasi berprestasi dapat disajikan seperti pada tabel II berikut ini:

Tabel IV-1. Hasil Angket Motivasi Berprestasi Siswa

\begin{tabular}{|c|c|c|c|}
\hline & PRA SIKLUS & SIKLUS I & SIKLUS II \\
\hline Rata-rata & 40 & 45 & 77 \\
\hline Tertinggi & 63 & 75 & 85 \\
\hline Terendah & 41 & 45 & 50 \\
\hline
\end{tabular}

Dari tabel II terlihat adanya peningkatan skor rata-rata motivasi berprestasi, dari skor rata-rata 45 pada tahap pra siklus menjadi sebesar 77 pada akhir tindakan pembelajaran Siklus II, sehingga terdapat peningkatan sebesar $32 \%$.

\section{Hasil belajar}

Hasil belajar siswa ditinjau dari nilai rata-rata dan ketuntasan belajar siswa pada kondisi pra siklus dapat disajikan seperti pada tabel II berikut ini:

Tabel IV-2 Hasil Belajar pada Kondisi Pra Siklus

\begin{tabular}{|c|c|c|}
\hline & Pengetahuan & Keterampilan \\
\hline Rata-rata & 45 & 60 \\
\hline Tuntas & 8 & 10 \\
\hline Belum tuntas & 14 & 12 \\
\hline \% Ketuntasan & $36 \%$ & $46 \%$ \\
\hline
\end{tabular}

Banyak siswa yang tuntas belajar 8 orang $(36 \%)$ dan terdapat 14 siswa (64\%) yang belum tuntas belajar. Sedangkan pada aspek keterampilan terdapat nilai rata-rata hasil belajar 60 dengan $10(46 \%)$ orang siswa tuntas 
belajar dan 12 siswa (54\%) siswa belum tuntas belajar.

Hasil belajar pada akhir siklus I dapat disajikan pada tabel IV berikut ini:

Tabel IV-3 Hasil Belajar pada Akhir Siklus I

\begin{tabular}{|l|c|c|}
\hline & Pengetahuan & Keterampilan \\
\hline Rata-rata & 75 & 80 \\
\hline Tuntas & 11 & 11 \\
\hline Tidak tuntas & 11 & 11 \\
\hline$\%$ Ketuntasan & $50 \%$ & $50 \%$ \\
\hline
\end{tabular}

Berdasarkan data pada tabel IV terlihat adanya peningkatan nilai ratarata dan persentase ketuntasan pada akhir siklus I.

Hasil belajar pada akhir siklus II dapat disajikan pada tabel $\mathrm{V}$ berikut ini:

Tabel V-4. Hasil belajar pada akhir Siklus II

\begin{tabular}{|l|c|c|}
\hline & Pengetahuan & Keterampilan \\
\hline Rata-rata & 77 & 85 \\
\hline Tuntas & 17 & 17 \\
\hline Tidak tuntas & 5 & 5 \\
\hline \% Ketuntasan & $77 \%$ & $77 \%$ \\
\hline
\end{tabular}

Berdasarkan data pada tabel V, terlihat adanya peningkatan hasil belajar. Nilai rata-rata pada aspek pengetahuan dan keterampilan.

Peningkatan hasil belajar ditinjau dari nilai rata-rata dan ketuntasan belajar siswa antara kondisi pra siklus, siklus I, siklus II, dan siklus III disajika pada tabel VI berikut:
Tabel IV-7 Peningkatan Hasil Belajar pada Aspek Pengetahuan antara Pra Siklus, Siklus I dan Siklus II

\begin{tabular}{|l|c|c|c|}
\hline & PRA SIKLUS & SIKLUS I & SIKLUS II \\
\hline Rata-rata & 45 & 75 & 77 \\
\hline \% Ketuntasan & 36 & 50 & 77 \\
\hline
\end{tabular}

Tabel IV-8 Peningkatan Hasil Belajar pada Aspek Keterampilan antara Pra Siklus, Siklus I dan Siklus II

\begin{tabular}{|l|c|c|c|}
\hline & PRA SIKLUS & SIKLUS I & SIKLUS II \\
\hline Rata-rata & 60 & 80 & 85 \\
\hline$\%$ Ketuntasan & 46 & 50 & 77 \\
\hline
\end{tabular}

Berdasarkan Tabel IV-7 diketahui bahwa terdapat peningkatan hasil belajar siswa pada siklus I dibandingkan hasil belajar siswa pada kondisi pra siklus. Namun peningkatan yang terjadi masih belum memenuhi indikator kinerja yang ditentukan pada penelitian ini.

Pada siklus II, dari Tabel IV-7 dapat menunjukkan bahwa hasil belajar pada siklus II ini mengalami peningkatan yang cukup signifikan dibandingkan hasil belajar siswa pada kondisi pra siklus. Selain itu hasil belajar siswa yang dicapai pada siklus II sudah memenuhi indikator kinerja yang telah ditentukan pada penelitian ini. Jadi dapat disimpulkan bahwa tindakan guru melaksanakan pembelajaran dengan menerapkan pembelajaran model Discovery Learning berbantuan Power Point dan LKS dapat meningkatkan hasil belajar siswa yang ditunjukkan dengan peningkatan nilai siswa setiap siklus. Disamping itu pembelajaran dengan 
menerapkan pembelajaran model Discovery Learning berbantuan Power Point dan LKS juga dapat meningkatkan motivasi berprestasi siswa, hal ini dapat ditunjukkan dalam tabel IV-1 yang menunjukkan perbandingan kondisi awal dan kondisi akhir motivasi berprestasi siswa pada pembelajaran matriks, dimana terdapat peningkatan yang signifikan, hal ini sejalan dengan penelitian yang telah dilakukan oleh (Suryanti, 2015) bahwa pembelajaran dengan menggunakan discovery learning mampu meningkatkan kemampuan pemecahan masalah yang dampaknya juga pada peningkatan prestasi hasil belajar. Berdasarkan hasil tersebut, maka tindakan yang dirumuskan yaitu: "Pembelajaran model Discovery Learning berbantuan media Power Point dan LKS untuk meningkatkan motivasi berprestasi dan hasil belajar matematika siswa" dapat dibuktikan kebenarannya.

\section{PENUTUP}

\section{Simpulan}

Berdasarkan temuan-temuan penelitian dan analisis, maka selanjutnya dapat diperoleh simpulan sebagai berikut:

1. Penerapan pembelajaran model Discovery Learning berbantuan Power Point dan LKS dapat meningkatkan motivasi berprestasi siswa kelas XI TSM 1 SMK Muhammadiyah 2 Jogoroto, semester gasal tahun pelajaran 2019/2020. Penggunaan media pembelajaran dalam proses belajar efektif untuk meningkatkan motivasi berprestasi siswa. Hal ini ditunjukkan dengan meningkatnya skor rata-rata motivasi berprestasi siswa dari 45 pada tahap Pra Siklus menjadi sebesar 75 pada akhir tindakan pembelajaran Siklus I, kemudian meningkat menjadi 77 pada akhir tindakan pembelajaran Siklus II,

2. Penerapan pembelajaran model Discovery Learning berbantuan Power Point dan LKS dapat meningkatkan hasil belajar matematika siswa kelas XI TSM 1 SMK Muhammadiyah 2 Jogoroto, semester gasal tahun pelajaran 2019/2020. Hal ini ditunjukkan dengan meningkatnya nilai rata-rata kelas yang diperoleh siswa baik pada aspek pengetahuan maupun keterampilan. Pada aspek pengetahuan, nilai rata-rata kelas pada tahap Pra Siklus, Siklus I, II berturut-turut adalah 45;75; dan 77 . Sedangkan pada aspek keterampilan, nilai rata-rata kelas pada tahap Pra 

adalah $60 ; 80$; dan 85 .

lainnya hendaknya tidak ragu

3. Penerapan pembelajaran model Discovery Learning berbantuan Power Point dan LKS meningkatkan motivasi berprestasi dan hasil belajar matematika siswa kelas XI TSM 1 SMK Muhammadiyah 2 Jogoroto, semester gasal tahun pelajaran 2019/2020. Penerapan pembelajaran model Discovery Learning berbantuan Power Point dan LKS dapat membantu siswa agar informasi yang dipelajarinya menjadi bermakna dan relevan untuk dirinya. Siswa berperan aktif dalam pembelajaran sehingga siswa tertarik, senang dan secara sadar menggunakan strategi-strategi mereka sendiri untuk belajar yang berdampak pada peningkatan motivasi berprestasi dan hasil belajar mereka terhadap pelajaran matematika.

\section{Saran}

\section{Bagi Siswa}

a. Siswa sebaiknya terlebih dahulu mempersiapkan diri dengan materi yang akan dipelajari, sehingga siswa telah memiliki bekal untuk berdiskusi di kelas saat pembelajaran berlangsung.

b. Saat berkelompok, siswa yang memiliki kemampuan yang baik untuk membagi pengetahuan atau informasi kepada siswa yang belum paham tentang suatu hal. Dan sebaliknya, bagi siswa yang belum memahami materi yang dipelajari, hendaknya tidak malu untuk bertanya kepada siswa lain yang sudah memahami materi tersebut.

\section{Bagi Guru}

a. Guru hendaknya memiliki kemampuan berinovasi dalam menerapkan model pembelajaran dan media untuk menyampaikan materi pembelajaran

b. Guru hendaknya mau membuka diri untuk menerima saran, masukan, dan kritikan agar bisa memperbaiki kualitas pembelajarannya.

3. Bagi Pihak Sekolah

a. Memberi kesempatan guru agar aktif dalam mengikuti kegiatankegiatan yang sifatnya menambah pengetahuan, seperti: seminar, simposium, loka karya, diklat, dan lain-lain.

\section{DAFTAR PUSTAKA}

Benny A. Pribadi. 2011. Model Desain Sistem Pembelajaran. Jakarta: PT Dian Rakyat. 
Heris Hendriana. 2014. Panduan bagi Guru, Penelitian Tindakan Kelas suatu Karya Tulis Ilmiah. Bandung: PT Refika Aditama.

Herman Hudojo. 1979. Pengembangan Kurikulum Matematika dan Pelaksanaannya di Depan Kelas. Surabaya: Usaha Nasional.

Suryanti, S. (2015). Peningkatan kepercayaan diri dan kemampuan pemecahan masalah mahasiswa pada mata kuliah matematika diskrit melalui discovery learning. DIDAKTIKA: Jurnal Pemikiran Pendidikan, 22(1), 64-73. https://doi.org/doi:10.1234/didakti ka.v22i1.148 